\title{
Consequences of coloniality: influence of colony form and size on feeding success in the bryozoan Membranipora membranacea
}

\author{
Marney C. Pratt* \\ Biology Department, Duke University, Box 90338, Durham, North Carolina 27708, USA \\ Present address: Department of Biology, Bowdoin College, 6500 College Station, Brunswick, Maine 04011, USA
}

\begin{abstract}
Colonial animals can grow in a wide variety of shapes and sizes, but certain forms have apparently evolved several times in different taxa. Using adaptive arguments to explain the evolution of colony form is tempting, but when testing the functional advantage of different colony forms, controlling for species differences is difficult. In this study, 1 species of bryozoan, Membranipora membranacea (Linnaeus, 1767), was grown into different colony shapes and sizes to test how colony form affected feeding performance. Clearance rate was measured for 3 colony forms (encrusting sheet, erect sheet, erect tree), and zooid ingestion rate was measured for 5 colony sizes (comprising of 1, 8, 16,125 , or 975 zooids). The 2 erect forms had higher clearance rates than did the encrusting sheet form at a freestream velocity of $3 \mathrm{~cm} \mathrm{~s}^{-1}$. At this velocity, erect colonies experienced less refiltration and yet benefited from feeding in a downstream wake. For encrusting colonies the change in ingestion rate per zooid with colony size was non-linear. Overall, zooid ingestion rate increased from 1 to 16 zooids, decreased for small colonies (with 125 zooids), and then increased again for medium colonies (with $\sim 975$ zooids). Colonies with 8 or more zooids had higher feeding success than single zooids, suggesting a feeding advantage to zooids in a colony. Conversely, small and medium colonies had lower mean ingestion rates than colonies with 8 or 16 zooids, suggesting a feeding cost for increasing beyond a relatively small size.
\end{abstract}

KEY WORDS: Membranipora membranacea $\cdot$ Bryozoan $\cdot$ Colony form $\cdot$ Colony size $\cdot$ Particle capture Suspension-feeding $\cdot$ Clearance rate

Resale or republication not permitted without written consent of the publisher

\section{INTRODUCTION}

Colonial animals such as corals, hydrozoans, ascidians and bryozoans exhibit a wide diversity of colony growth forms, but these growth forms represent only a few basic categories. One way of classifying the basic growth forms is as runners, sheets or trees (Jackson 1979). In the runner form, the replicated units, or modules, in the colony bud end-on-end into a relatively linear colony, the modules in the sheet form bud into a wider, but still relatively flat colony, and the modules in the tree form bud into a more 3-dimensional branching shape. These basic categories can then be divided into encrusting and erect forms. Encrusting forms have most of their surface area attached to the substratum, while erect forms attach only a small proportion. Many colonial animals can bud asexually in any direction, so theoretically any colony shape should be possible; however, only some of the possible forms have evolved (McKinney \& Raup 1982, McGhee \& McKinney 2000, Starcher \& McGhee 2000). Indeed, relatively similar forms have evolved several times in different phyla, which suggests convergence. Still, demonstrating whether such traits are adaptive is difficult.

Bryozoans are colonial animals made of asexually budded units called zooids that exhibit all the basic categories of colony growth forms. Erect bryozoan species were more common in the Paleozoic than were encrusting species, but in the Recent there are nearly twice as many encrusting as erect species (McKinney 
\& Jackson 1991). Previous hypotheses to explain this pattern have focused on spatial limitation or risk of dislodgement (Buss 1979a, Jackson 1979, McKinney \& Jackson 1991), while only more recently has the selective role of food acquisition been explored (Eckman \& Okamura 1998, Okamura et al. 2001, Pratt 2004). So far, there are theories (Buss 1979b, Jackson 1979, Coates \& Jackson 1985, Harper 1985, McKinney \& Jackson 1991, Lasker \& Sanchez 2002), but few experimental studies that test the advantages and disadvantages of different colony forms, especially in bryozoans. Some studies have shown how colony shape affects feeding behavior and patterns of colony feeding currents (Winston 1978, 1979, McKinney et al. 1986, McKinney 1989, 1990, McKinney \& Jackson 1991), but less is known about how colony form affects actual food capture (Okamura 1984, 1985, 1990).

The size of a colony may also have important consequences for feeding performance. While many studies have looked at the order, direction and rate of zooid budding as bryozoan colonies grow (Silen 1982, Lidgard 1985a,b, Silen 1987, Cancino \& Hughes 1988, Taylor \& Wilson 1994), relatively few have focused on the consequences of colony size on feeding performance. An exception is work by Okamura $(1984,1985)$ and Okamura \& Doolan (1993), who found that larger colonies generally have higher feeding success than smaller colonies; however, these studies only compared 2 sizes of colonies.

Colony size influences feeding performance in bryozoans in part because of the way feeding currents are generated and vented. Bryozoans create the feeding current by means of a ciliated crown of tentacles called a lophophore. A stronger, more effective downward feeding current is generated as more lophophores are added to a colony; however, the rate of moving current through the colony is limited by the subsequent increase in pressure in the incurrent space created under a tightly packed canopy of lophophores (Dick 1987, Grünbaum 1995, Eckman \& Okamura 1998). The pressure under the lophophores is relieved by the presence of excurrent areas. Small colonies have sufficient excurrent area on the perimeter relative to incurrent area. However, as an encrusting sheet colony increases in size, the total area of the colony increases faster than does the perimeter of the colony, so the total cross-sectional area of the excurrent space decreases relative to the total incurrent area (Dick 1987). Thus, larger bryozoan sheet colonies often create local excurrent spaces in the interior of the colony called excurrent chimneys. One cost of increasing size in a sheet colony may be that proportionally more colony area must be sacrificed to excurrent area as the colony grows.

Erect colonies can avoid size-specific limitations in excurrent space as long as the branches are relatively thin, because the excurrent area along the colony perimeter does not decrease as the area of the colony increases. However, the need to devote space to excurrent chimneys as a sheet colony grows may be at least partially offset by the feeding advantage of having zooids packed tightly together (Eckman \& Okamura 1998, Pratt 2004).

In this study, a single species, Membranipora membranacea, was grown into different colony forms and sizes to test how colony form can affect feeding performance. When testing the functional advantage of different colony forms, controlling for species differences is difficult. By growing a single species in several forms, it was possible to factor out potentially confounding differences that arise in interspecies comparisons.

\section{MATERIALS AND METHODS}

Bryozoan collection and maintenance. Membranipora membranacea (Linnaeus, 1767) (hereafter referred to as Membranipora) grows naturally as an encrusting sheet and tends to be most abundant on large relatively flat macroalgae such as kelps; however, in the field it occasionally grows on other substrata such as thinly branched algae. Colonies of Membranipora growing on the red alga Mazzaella splendens were collected from the floating docks at the Friday Harbor Laboratories in Friday Harbor, Washington. Colonies were peeled off the algae, placed onto a substratum in a dish of seawater, and allowed to grow until firmly attached (usually 1 to $2 \mathrm{~d}$ ). Once firmly attached, colonies were placed in racks and hung off the floating docks to feed in their natural habitat until used in experiments.

Colony form. After colonies had been peeled off algae, they were cut into equal-sized pieces and placed onto 3 different substrata: glass slides, broad-leafed plastic aquarium plants, and more thinly branched plastic aquarium plants. The colony pieces then grew to cover the substrata, which resulted in 3 different colony forms: encrusting sheets, erect sheets and erect trees (Fig. 1).

All experiments were run in a recirculating flow tank $(6 \times 6 \times 40 \mathrm{~cm}$ working section, Dolphin DP270 pump) containing $2000 \mathrm{ml}$ of $0.45 \mu \mathrm{m}$-filtered seawater at $12^{\circ} \mathrm{C}$. Clearance rate (the number of particles cleared from a volume of water per unit time) was measured for each of the 3 forms at 3 freestream water velocities, 0 , 0.6 , and $3 \mathrm{~cm} \mathrm{~s}^{-1}$. Velocity as a function of height was measured by flow-visualization (see subsection 'Flow visualization'). Freestream velocity was estimated by measuring the mean velocity between 2.6 and $3.1 \mathrm{~cm}$ above the bottom. Shear velocity $\left(U^{*}\right)$ was calculated as

$$
U^{*}=(v \mathrm{~d} U / \mathrm{d} z)^{1 / 2}
$$


(Vogel 1994), where $v$ is the kinematic viscosity (in this case $v=0.0128 \mathrm{~cm}^{2} \mathrm{~s}^{-1}$ ), and $z$ is height from the bottom.

The initial algal concentration for each experiment was approximately 5000 Rhodomonas sp. cells $\mathrm{ml}^{-1}$, and $0.5 \mathrm{ml}$ samples were taken every $15 \mathrm{~min}$ for 90 min. The number of Rhodomonas sp. cells was
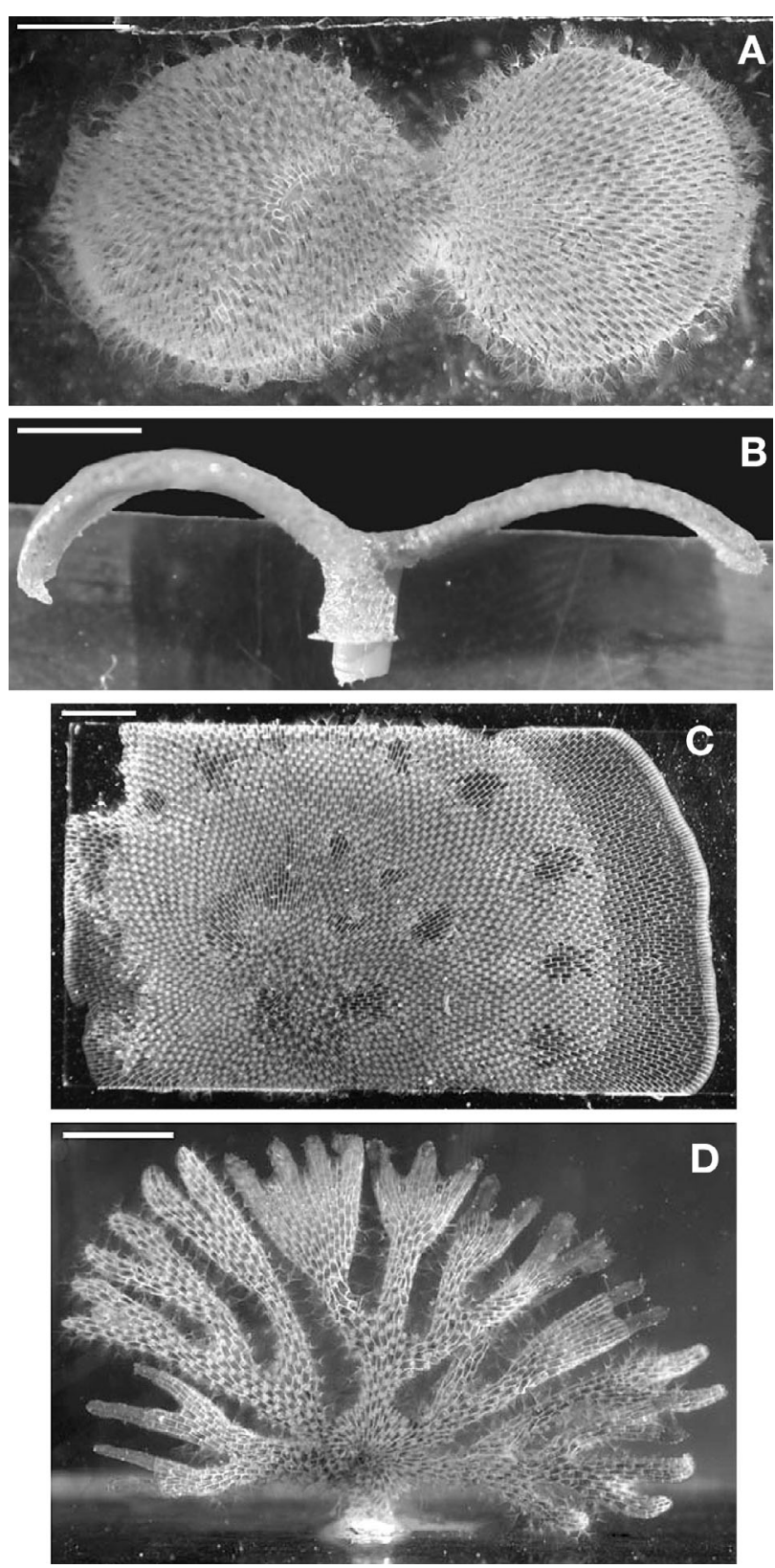

Fig. 1. Examples of substrata used to create colonies of 3 different colony forms of Membranipora membranacea. (A) Top and (B) side view of broad-leafed plastic aquarium plant used to create erect sheet colonies; (C) top view of glass side used to create encrusting sheet colonies; (D) front view of thinly branched plastic aquarium plant used to create erect tree colonies. Scale bars $=2 \mathrm{~mm}$ counted in 20 to 30 drops ( $1 \mathrm{\mu l}$ each) using a compound microscope at $100 \times$ to determine the sample's algal cell concentration. Clearance rate $(F)$ was calculated as:

$$
F=V\left[\ln \left(C_{0} / C_{t}\right)\right] /(A t)
$$

where $V$ is the volume of water in the flow tank $(2000 \mathrm{ml}), t$ is time, $C_{0}$ is the initial algal cell concentration, $C_{t}$ is the algal cell concentration at time $t$, and $A$ is the area of the colony where there was actively feeding zooids. The change in algal cell concentration as a function of time was fitted by least-squares regression. Only experiments with regressions that had $\mathrm{r}^{2}>0.95$ were used for further analysis (Lisbjerg \& Petersen 2001). Control experiments at each of the 3 velocities were run without any colonies present to check for settling or loss of algal cells. The amount of algal concentration change when no colony was present was subtracted from the calculated clearance rates in the experiments with colonies present.

After each experiment, a photograph of each colony was taken with a digital camera (Nikon CoolPix 995), and the area was measured using digital imaging software (Scion Image, Version 3b). Erect colonies were flattened and photographed front and back (for erect trees) or top, bottom and side (for erect sheets). Only some of the zooids in the colony actively ate during experiments, and these could be identified by the bright red coloring of the Rhodomonas sp. cells ingested. Both total area and the area of feeding zooids (active area) were measured. Since the 2 erect forms have more perimeter for excurrent flow, I expected that the encrusting form would have more area devoted to excurrent space within the colony (i.e. the encrusting form would have less active area for a given total area than the 2 erect forms).

Colony size. Ingestion rate was measured in encrusting Membranipora colonies of 5 different sizes: 1 zooid, 8 zooids, 16 zooids, small colonies (before any excurrent chimneys had formed, with mean area of $0.14 \pm 0.06 \mathrm{~cm}^{2}, \sim 125$ zooids), and medium colonies (after a few excurrent chimneys had formed, with mean area of $3.12 \pm 0.98 \mathrm{~cm}^{2}, \sim 975$ zooids). Small and medium colonies were grown naturally to the appropriate size, while the 1-, 8-, and 16-zooid treatments were dissected down from larger colonies using a scalpel and fine forceps. I have assumed that the dissections did not adversely affect the feeding ability of the remaining zooids in the dissected treatments once they were given a few days to recover, since previous work had suggested that dissections do not affect the cilia-generated feeding current at the level of the lophophore (Pratt 2004).

All feeding experiments were conducted in a recirculating flow tank (working section $18 \times 10.2 \times 70 \mathrm{~cm}$; after Vogel \& LaBarbera 1978) filled with $0.45 \mu \mathrm{m}$ - 
filtered seawater at $12^{\circ} \mathrm{C}$. Experiments were run at 1 of 3 freestream velocities: $0,0.5$ and $2.7 \mathrm{~cm} \mathrm{~s}^{-1}$. The freestream velocity was estimated by measuring the mean velocity between 2.5 and $4.5 \mathrm{~cm}$ above the bottom, and shear velocity was calculated as above (Eq. 1).

Blue-dyed polystyrene beads (mean diameter $=10.3 \mu \mathrm{m}$, $\mathrm{SD}=0.94 \mu \mathrm{m}$, density $=1050 \mathrm{~kg} \mathrm{~m}^{-3}$ ) at a concentration of 1000 beads $\mathrm{ml}^{-1}$ were used as food particles. Bryozoans have been shown to ingest large quantities of beads (Okamura 1984, 1985, Pratt 2004), and observations of Membranipora zooids feeding on beads show that they do not reject the beads (M. C. Pratt pers. obs.). After the correct particle concentration had been established in the tank and the flow was steady, the glass slides were positioned flush with the bottom of the flow tank so only bryozoans protruded into the flow. After feeding for $10 \mathrm{~min}$, colonies were removed, fixed in formalin, rinsed in $70 \% \mathrm{EtOH}$, and cleared in $50 \%$ glycerol. The beads ingested by zooids in each treatment were counted using a compound microscope at $100 \times$. The number of beads ingested was counted for all zooids in all treatments except in the medium colonies. In the medium colonies, zooid ingestion rate was measured for a haphazardly chosen subset of the total zooids. Both total area and active area of the small and medium colonies were measured using the same methods as described above; active and total areas were also measured for a group of even larger colonies to include a wider size range in this analysis. Since the perimeter will not increase as fast as the area, I expected that more area would have to be devoted to excurrent chimneys as the colony grows (i.e. there should be less active area for a given total area for larger colonies).

Flow visualization. Water flow was visualized to determine tank velocity profiles and to compare feeding currents of different treatments. Water in the tank was seeded with nearly neutrally buoyant particles (cornstarch particles, $\sim 20 \mu \mathrm{m}$ in diameter). The flow field was illuminated with a $1 \mathrm{~mm}$-thick laser-light sheet (Lasiris SNF laser, $100 \mathrm{~mW}, 670 \mathrm{~nm}$, focusable single line with $20^{\circ}$ fan angle) to obtain a 2-dimensional view. Videos were recorded using a digital video camera (Sony DCR TRV900 with two + 4 diopter close-up filters) with the optical axis perpendicular to the light sheet.

I used 3 different techniques of flow visualization. The first technique, digital particle image velocimetry (DPIV), calculates velocity vectors of the entire flow field by conducting subimage cross-correlations on pairs of video images (FlowVIS, Version 2). In cases where DPIV was not able to resolve velocity vectors reliably, the flow was analyzed by manually tracking particles frame by frame using the second flow-visualization method, particle tracking velocimetry (PTV).
The third method was essentially the video equivalent of a long-exposure photograph, whereby many successive video frames were laid on top of each other using a macro in Scion Image (Version 3b, macro developed by $M$. von Dassow, U. C. Berkeley). When PTV was used to measure incurrent velocities, only particles that entered the center of a lophophore in the center of the colony were tracked, since velocity is generally greatest in the center of the lophophore (Larsen \& Riisgård 2002). Once a particle was chosen, it was tracked as far away from the colony as it was visible.

Data analysis. Since the entire volume of water in the flow tank was only sufficiently mixed at the highest velocity tested, comparison of clearance rates among forms was only assessed at $3 \mathrm{~cm} \mathrm{~s}^{-1}$ by a 1-way ANOVA (SAS 8.02, PROC MIXED). A posteriori pairwise comparisons were performed using the Tukey-Kramer adjustment.

A 2-way mixed ANOVA was used to measure the effects of colony size and water velocity on zooid ingestion rate. Zooid ingestion rate is defined as the number of beads eaten zooid ${ }^{-1} \mathrm{~min}^{-1}$. Size (1 zooid, 8 zooids, 16 zooids, small colonies and medium colonies) and velocity $\left(0,0.5\right.$, and $\left.2.7 \mathrm{~cm} \mathrm{~s}^{-1}\right)$ were fixed effects, while colony (4 or more colonies per size by velocity treatment) was the random effect. Samples of the 8- and 16-zooid treatments were insufficient to test at $0.5 \mathrm{~cm} \mathrm{~s}^{-1}$, but the other 3 size classes were tested at all 3 velocities. A posteriori pairwise comparisons were done using the Tukey-Kramer adjustment.

ANCOVA was used to test the effect of colony form or size on the relationship between the active area and total area in a colony, where colony forms or sizes were the fixed effects and clone was the random effect. Active and total colony areas were transformed with natural logarithms.

Particle tracking velocimetry (PTV) was used to measure the incurrent flow in the 5 size treatments. Colonies were filmed in approximately still water, and 6 particles were tracked for 2 colonies of each size treatment to measure the velocity of the feeding currents as a function of distance from the lophophores. A mixed-model ANCOVA compared how the different treatments affected the variation of incurrent velocity with distance from the lophophore. The fixed effect was size (5 size treatments), and the random effects were the number of colonies ( 2 colonies per size treatment), the number of particles used for tracking velocity (6 particles per colony per size treatment), and the observations of particle velocity at a particular distance from the lophophores. If the slopes differed, then a posteriori pairwise comparisons were made at specific values of the covariate using the Tukey-Kramer adjustment. Incurrent velocities were always logtransformed before analysis. 
Table 1. Flow conditions in flow tank during each experiment. Dimensions of tanks in each experiment were $6 \times 6 \times 40 \mathrm{~cm}$ (filled to $5 \mathrm{~cm}$ depth) and $18 \times 10.2 \times 70 \mathrm{~cm}$ (filled to $13 \mathrm{~cm}$ depth) in experiments investigating effect of colony form and size respectively. $U$ : ambient velocity; $z$ : height above bottom

\begin{tabular}{|ccllll|}
\hline \multirow{2}{*}{ Expt } & $\begin{array}{c}\text { Freestream velocity } \\
\mathrm{cm} \mathrm{s}^{-1}(\text { mean } \pm \mathrm{SD})\end{array}$ & \multicolumn{1}{c}{ Eq. } & $\begin{array}{l}\text { Linear regression } \\
\text { Height range }(\mathrm{cm})\end{array}$ & $\mathrm{R}^{2}$ & $\begin{array}{c}\text { Shear velocity } \\
U^{*}\left(\mathrm{~cm} \mathrm{~s}^{-1}\right)\end{array}$ \\
\hline \multirow{2}{*}{ Form } & $0.6 \pm 0.03$ & $U=0.23 z$ & (for $z<2.4)$ & 0.96 & 0.054 \\
& $3.0 \pm 0.30$ & $U=3.7 z$ & (for $z<0.6)$ & 0.94 & 0.22 \\
Size & $0.5 \pm 0.01$ & $U=0.33 z$ & (for $z<1)$ & 0.93 & 0.065 \\
& $2.7 \pm 0.06$ & $U=2.7 z$ & (for $z<1)$ & 0.95 & 0.19 \\
& & & & & \\
\hline
\end{tabular}

forms had significantly higher clearance rates than the encrusting sheet $\left(t_{6}=4.05, \mathrm{p}=0.016\right.$ and $t_{6}=3.21, \mathrm{p}=0.05$ respectively), while the 2 erect forms were not significantly different from each other $\left(t_{6}=-1.25, \mathrm{p}=0.47\right)$.

Active area did not scale differently with total area among colony forms $\left(F_{2,21}=0.28, \mathrm{p}=\right.$ $0.76)$, so a common slope was used and the intercepts compared. The intercepts of the two

\section{RESULTS}

\section{Flow conditions}

The flow conditions in the 2 experiments were similar but not identical (Table 1). Estimates of $U^{*}$ on kelp blades range between 0.22 and $0.60 \mathrm{~cm} \mathrm{~s}^{-1}$ (Koehl \& Alberte 1988), thus the velocities used in this study ( $U^{*}$ between 0 and $0.22 \mathrm{~cm} \mathrm{~s}^{-1}$ ) are likely to be at the lower end of the range of velocities experienced by bryozoans living on kelps in the field.

\section{Colony form}

\section{Feeding performance}

Colony form significantly affected clearance rate $\left(F_{2,6}=8.62, \mathrm{p}=0.017\right.$; Fig. 2). A posteriori pairwise comparisons revealed that the erect sheet and tree

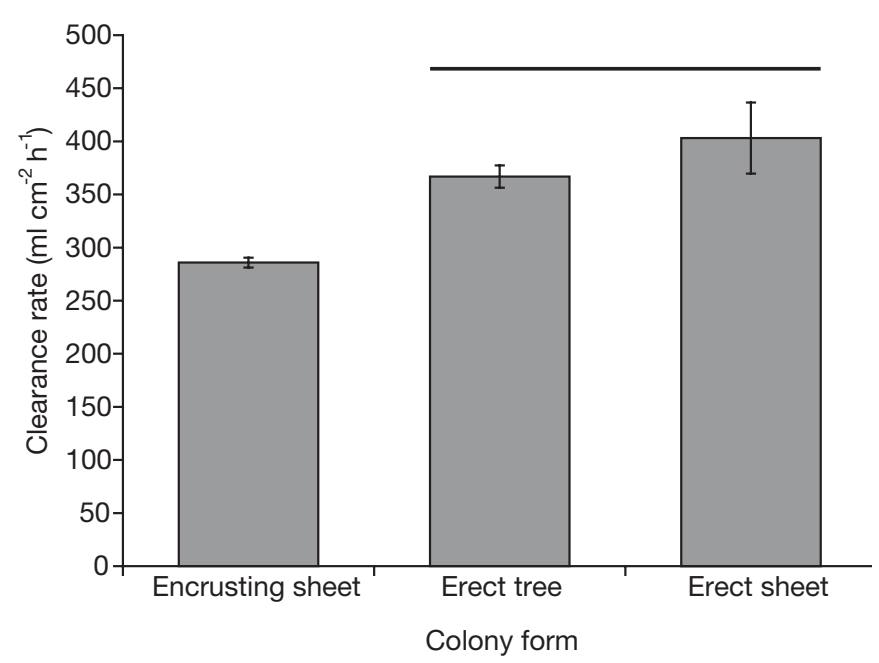

Fig. 2. Membranipora membranacea. Mean $( \pm \mathrm{SE})$ clearance rates of 3 different colony forms at $3 \mathrm{~cm} \mathrm{~s}^{-1}$ freestream velocity. Line above bars indicates colony forms that were not significantly different $(p>0.05)$ erect forms were not significantly different $\left(t_{23}=0.36\right.$, $p=0.72$ ), so the data for the erect forms were pooled. As predicted, the encrusting form had a significantly lower active area for a given total area than the 2 erect forms $\left(F_{1,24}=28.02, \mathrm{p}<0.0001\right.$; Table 2$)$.

\section{Flow visualization}

Most of the zooids of erect colonies were located much higher above the substratum than those in the encrusting colonies, and as a result they experienced higher ambient velocities (Table 3).

In general, excurrent flow from chimneys or branch tips created substantial mixing in all colony forms (Fig. 3). Often, the strong excurrent flow directed most of the filtered water away from the incurrent flow, but in some cases there was refiltration of excurrent water. The highest proportion of zooids experiencing refiltration was in the encrusting sheet colonies at the highest velocity $\left(3 \mathrm{~cm} \mathrm{~s}^{-1}\right)$. Both erect colonies probably experienced some refiltration at all velocities, but a downstream eddy formed at the higher velocities caused substantial mixing.

Table 2. Membranipora membranacea. Relationship between active and total area $\left(\mathrm{cm}^{2}\right)$ for colonies of differing forms and sizes. Areas were natural logarithm-transformed so that form of equation was $\ln$ active area $=$ slope $\times \ln$ total area + intercept. Colonies were all encrusting sheets in size comparison (value in parentheses is mean $\pm \mathrm{SD}$ of total area for each size treatment)

\begin{tabular}{|lcc|}
\hline & Slope & Intercept \\
\hline Form & & \\
$\quad$ Erect sheets and trees & 1.28 & -0.64 \\
Encrusting sheets & 1.28 & -0.96 \\
Size & & \\
Small $\left(0.14 \pm 0.017 \mathrm{~cm}^{2}\right)$ & 0.95 & -1.11 \\
Medium $\left(3.12 \pm 0.24 \mathrm{~cm}^{2}\right)$ & 0.95 & -0.50 \\
Large $\left(16.62 \pm 1.17 \mathrm{~cm}^{2}\right)$ & 0.95 & -0.054 \\
\hline
\end{tabular}



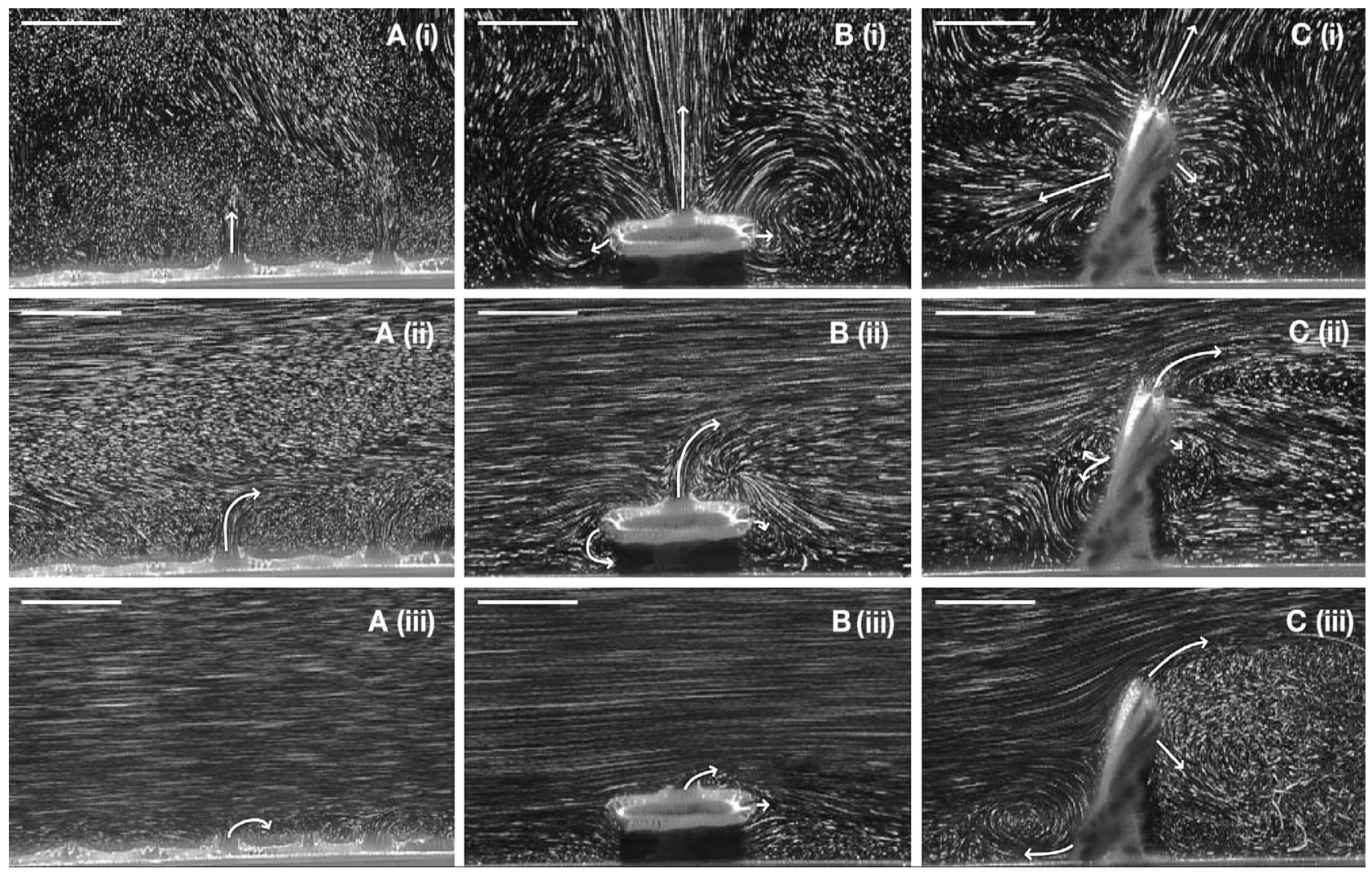

Fig. 3. Membranipora membranacea. Examples of flow around colonies grown on 3 different surfaces at 3 freestream velocities. (A) Encrusting sheet; (B) erect sheet; (C) erect tree; (i) $0 \mathrm{~cm} \mathrm{~s}^{-1}$; (ii) $0.6 \mathrm{~cm} \mathrm{~s}^{-1}$; (iii) $3 \mathrm{~cm} \mathrm{~s}^{-1}$. Images created by overlapping 121 frames of video $\left(\sim 4 \mathrm{~s}\right.$ ); taken from side with freestream flow from left to right (when $>0 \mathrm{~cm} \mathrm{~s}^{-1}$ ). Arrows indicate direction of excurrent flow. Scale bars $=1 \mathrm{~cm}$

\section{Colony size}

Feeding performance

Size, velocity and colony all had significant effects on zooid ingestion rate, but the interaction between colony size and water velocity did not have a significant effect (Fig. 4). Overall, ingestion rate increased from 1 to 16 zooids, decreased for the small colonies, and then increased again for the medium colonies. The 8- and 16zooid treatments had significantly greater mean inges-

Table 3. Membranipora membranacea. Horizontal velocities $\left(\mathrm{cm} \mathrm{s}^{-1}\right)$ experienced by lophophores at typical range of lophophore heights (distance above bottom of tank in parentheses) for colonies in both experiments

\begin{tabular}{|lcccc|}
\hline Expt & $\begin{array}{c}\text { Freestream } \\
\text { velocity }\end{array}$ & $\begin{array}{c}\text { Encrusting } \\
\text { sheet }\end{array}$ & Erect sheet & Erect tree \\
\hline Form & & $(0.12-0.33)$ & $(0.32-0.80)$ & $(0.12-1.9)$ \\
& 0.6 & $0.028-0.076$ & $0.074-0.18$ & $0.028-0.44$ \\
& 3 & $0.44-1.2$ & $1.2-3.0$ & $0.44-7.0$ \\
Size & 0.5 & $0.040-0.11$ & & \\
& 2.7 & $0.32-0.89$ & & \\
\hline
\end{tabular}

tion rates than the single zooid or small or medium colonies (all pairwise comparisons, $\mathrm{p}<0.0001$ ); the medium colonies had significantly greater mean ingestion rates than the small colonies $\left(t_{30}=-2.47, \mathrm{p}=0.043\right)$; and all other pairwise comparisons between sizes were not significantly different (all $p>0.05$ ). The only significant difference between velocity treatments was that ingestion rate was significantly higher at $2.7 \mathrm{~cm} \mathrm{~s}^{-1}$ than at $0 \mathrm{~cm} \mathrm{~s}^{-1}\left(t_{49}=-2.95, \mathrm{p}=0.0048\right)$.

No significant difference was found in how active colony area scaled with total colony area between the small, medium and large colonies $\left(F_{2,32}=2.00, \mathrm{p}=0.15\right)$, so a common slope model was used. The intercepts differed significantly $\left(F_{1,34}=161.84\right.$, $\mathrm{p}<0.0001$; Table 2); however, differences were not as predicted and large colonies had significantly greater active area for a given total area than medium colonies $\left(t_{34}=-3.20\right.$, $\mathrm{p}=0.0083$ ), and medium colonies had significantly greater active area than small colonies $\left(t_{34}=-2.53, \mathrm{p}=0.041\right)$. 


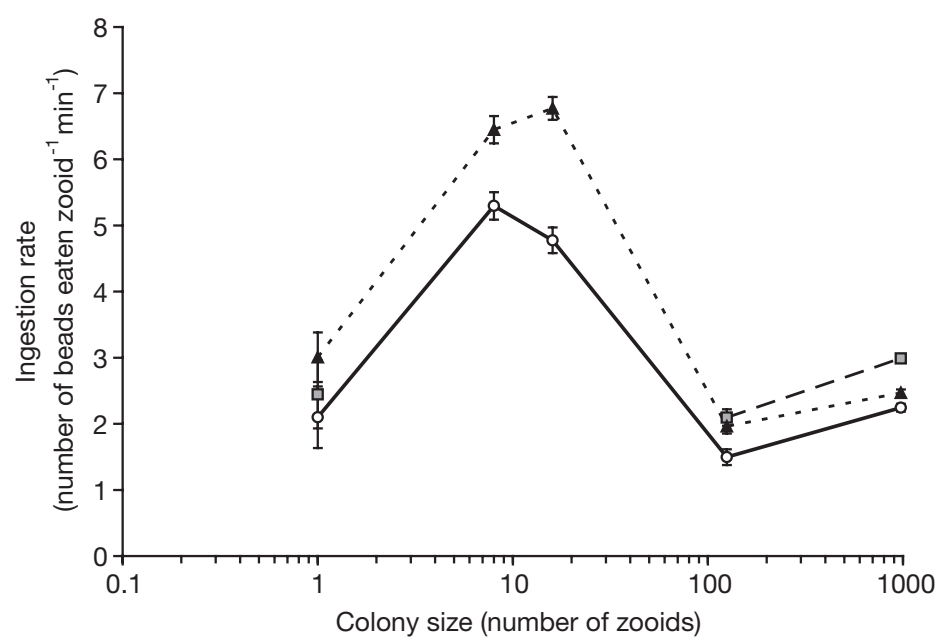

Fig. 4. Membranipora membranacea. Zooid ingestion rate as a function of zooid number (log-scale). Number of zooids for small ( 125 zooids) and medium ( 975 zooids) colonies is mean number of zooids per colony for each treatment. (O) $0 \mathrm{~cm} \mathrm{~s}^{-1}$; (口) $0.5 \mathrm{~cm} \mathrm{~s}^{-1}$; (ム) $2.7 \mathrm{~cm} \mathrm{~s}^{-1}$. Data points are least-squares means \pm SE. Size $\left(F_{4,64.6}=32.20, p<0.0001\right)$, velocity $\left(F_{2,69.7}=4.54, \mathrm{p}=0.014\right)$, and colony $\left(\chi_{1}^{2}=862\right.$, $\mathrm{p}<0.0001$ ) all had significant effect on zooid ingestion rate, but interaction between colony size and water velocity did $\operatorname{not}\left(F_{6,67.6}=0.76, \mathrm{p}=0.60\right)$

\section{Flow visualization}

Incurrent velocity scaled significantly differently with distance from the lophophores among size treatments, and a significant amount of variation was contributed by the colony and particle random factors (Fig. 5). In general, the slope decreased with increasing colony size, indicating that velocity dropped more with distance from the lophophores for small colonies than for larger colonies. Since the slopes were significantly different among treatments, a posteriori pairwise comparisons were made at $0.05 \mathrm{~cm}$ intervals between 0 and $0.20 \mathrm{~cm}$ above the lophophores. At $0 \mathrm{~cm}$, there was no significant difference between any of the size treatments ( $p>0.05$ for each), which supports the assumption that the dissections did not affect cilia-created feeding currents at the level of the lophophore. At $0.05 \mathrm{~cm}$ and above, the 1-zooid treatment had significantly lower incurrent velocity than each of the other size classes ( $p<0.05$ for each). At $0.15 \mathrm{~cm}$ and above, the 8-zooid treatment had significantly lower incurrent velocity than the small or medium colony treatments ( $p<0.05$ for each). At $0.20 \mathrm{~cm}$, the 8-zooid treatment had significantly lower velocity than the 16 -zooid treatment $(p=0.046)$, but the 16-zooid treatment had lower velocity than the medium colonies $(\mathrm{p}=0.045)$.

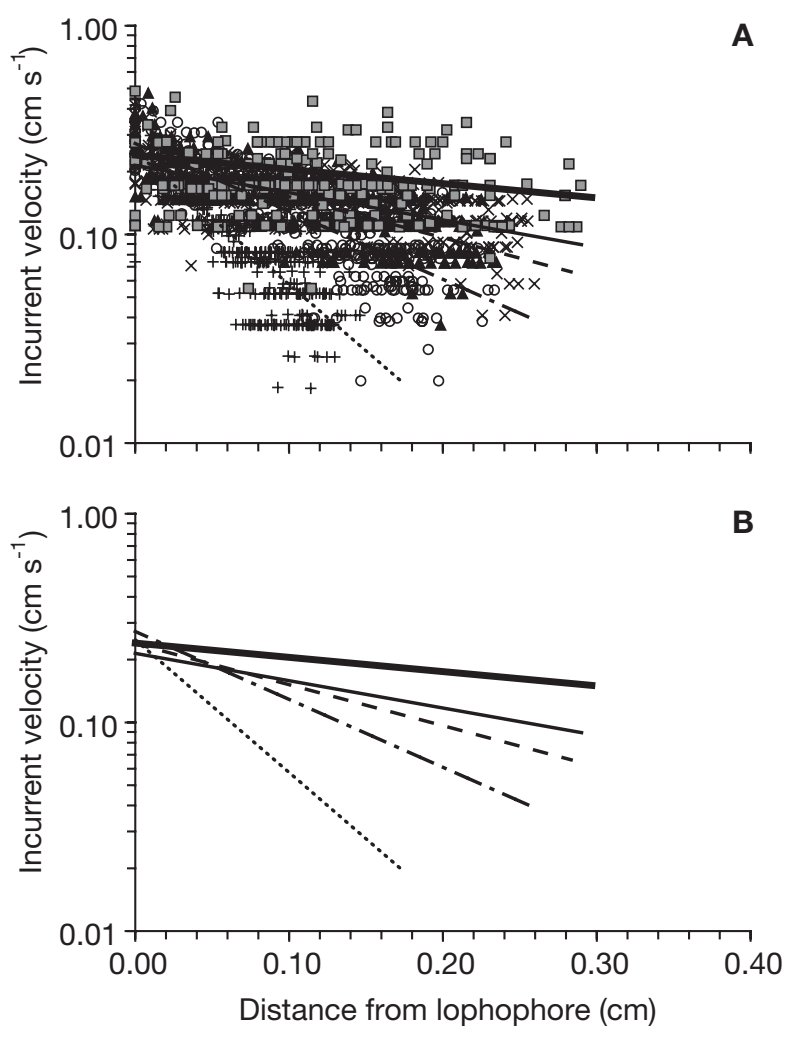

Fig. 5. Membranipora membranacea. Incurrent velocity (logscale) as a function of distance from lophophores for 5 colony sizes. (+) dotted line: single zooids; (O) dot-dashed line: 8 zooids; $(\mathbf{\Lambda})$ dashed line: 16 zooids; $(\times)$ thin continuous line: small colonies; $(\square)$ thick continuous line: medium colonies. In (B) data points are omitted to show general trends. Equations, in form ln (incurrent velocity) $=\beta$ (distance from lophophores) $+\alpha$ for each treatment are single zooids: $\beta=-14.63, \alpha=-1.39$; 8 zooids: $\beta=-7.49, \alpha=-1.30$; 16 zooids: $\beta=-4.49, \alpha=-1.43$; small colonies: $\beta=-3.02, \alpha=-1.54$; medium colonies: $\beta=$ $-1.57, \alpha=-1.42$. Slopes differed significantly among size treatments $\left(F_{4,1779}=183.26, \mathrm{p}<0.0001\right)$, and differences among colonies within a size class $\left(\chi_{1}^{2}=28.4, \mathrm{p}<0.0001\right)$ and particle trajectory within a colony $\left(\chi_{1}^{2}=20.9, \mathrm{p}<0.0001\right)$ added a significant amount of variation (see 'Results: Flow visualization' for a posteriori pairwise comparisons at specified values of covariate)

Colonies had more vertically directed incurrent flow than the single zooids (Figs. 6 \& 7). A quick measurement from the long-exposure images (Figs. 6 \& 7) of height above bottom from which colonies were able to draw particles revealed that treatments with 8 or 16 zooids and small colonies can draw particles 2 to 3 times further from the bottom than single zooids in stagnant water or a freestream velocity of $0.5 \mathrm{~cm} \mathrm{~s}^{-1}$ (Table 4). Excurrent chimneys complicate the flow patterns (Fig. 7), and thus make it difficult to interpret how far above the bottom a medium colony can capture a particle. 

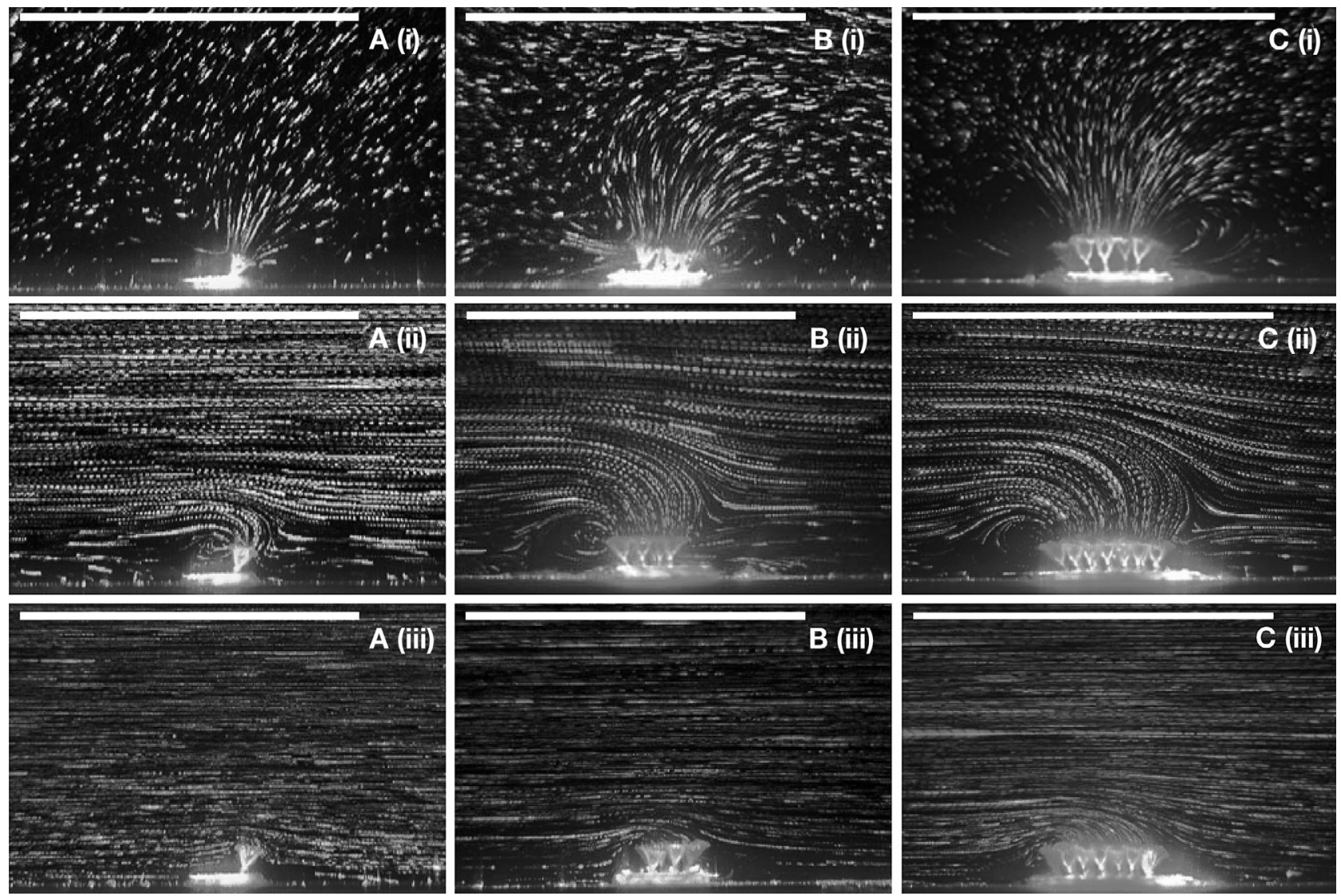

Fig. 6. Membranipora membranacea. Examples of flow around colonies of different sizes (three smallest colony sizes) at 3 freestream velocities: (A) 1 zooid; (B) 8 zooids; (C) 16 zooids; (i) $0 \mathrm{~cm} \mathrm{~s}^{-1}$; (ii) $0.5 \mathrm{~cm} \mathrm{~s}^{-1}$; (iii) $2.7 \mathrm{~cm} \mathrm{~s}^{-1}$. Image presentation and scale bars as in Fig. 3

In stagnant water, the excurrent flow from chimneys was mostly directed upward, with some recycling of excurrent water back down towards the colony and into the incurrent flow (Fig. 7B[i], C[i]). When there were 2 excurrent chimneys, their excurrents intermixed creat-

Table 4. Membranipora membranacea. Height above bottom from which particles were successfully drawn into lophophores of different sized colonies at 3 freestream velocities. Values in parentheses are ambient velocities $\left(\mathrm{cm} \mathrm{s}^{-1}\right)$ calculated from linear relationship between ambient velocity $(U)$ and height above bottom $(z)$ for 0.5 and $2.7 \mathrm{~cm} \mathrm{~s}^{-1}$ freestream velocities $\left(U_{0.5}=0.33 z, U_{2.7}=2.7 z\right)$. 1 : single zooid; $8: 8$ zooids; 16: 16 zooids; $\mathrm{S}$ : small colonies; M: medium colonies

\begin{tabular}{|lccc|}
\hline Treatment & \multicolumn{3}{c|}{$\begin{array}{c}\text { Height }(\mathrm{cm}) \text { at each } \\
\text { freestream velocity }\left(\mathrm{cm} \mathrm{s}^{-1}\right)\end{array}$} \\
& 0 & 0.5 & 2.7 \\
\hline 1 & 0.29 & $0.24(0.079)$ & $0.17(0.46)$ \\
8 & 0.80 & $0.47(0.16)$ & $0.19(0.51)$ \\
16 & 0.81 & $0.42(0.14)$ & $0.20(0.54)$ \\
$\mathrm{S}$ & 0.90 & $0.40(0.13)$ & $0.22(0.59)$ \\
$\mathrm{M}$ & 0.68 & $0.82(0.27)$ & $0.39(1.0)$ \\
\hline
\end{tabular}

ing a space between them just above the colony where water recirculated. When the freestream velocity was 0.5 or $2.7 \mathrm{~cm} \mathrm{~s}^{-1}$, the excurrent flow was directed upward but then deflected downstream away from the colony and an eddy generally formed downstream of the chimney. The flow in the eddy downstream of the chimney was slowed, which either could increase particle capture by slowing the particles enough to be deflected into the incurrent flow or decrease particle capture because of refiltration. Decreased particle capture from refiltration is highly likely in an eddy such as that created between 2 chimneys (Fig. 7C).

\section{DISCUSSION}

\section{Colony form}

To my knowledge, this is the first time that feeding performance has been measured in different colony forms within the same species. For Membranipora, the 2 erect colony forms had higher clearance rates than did 

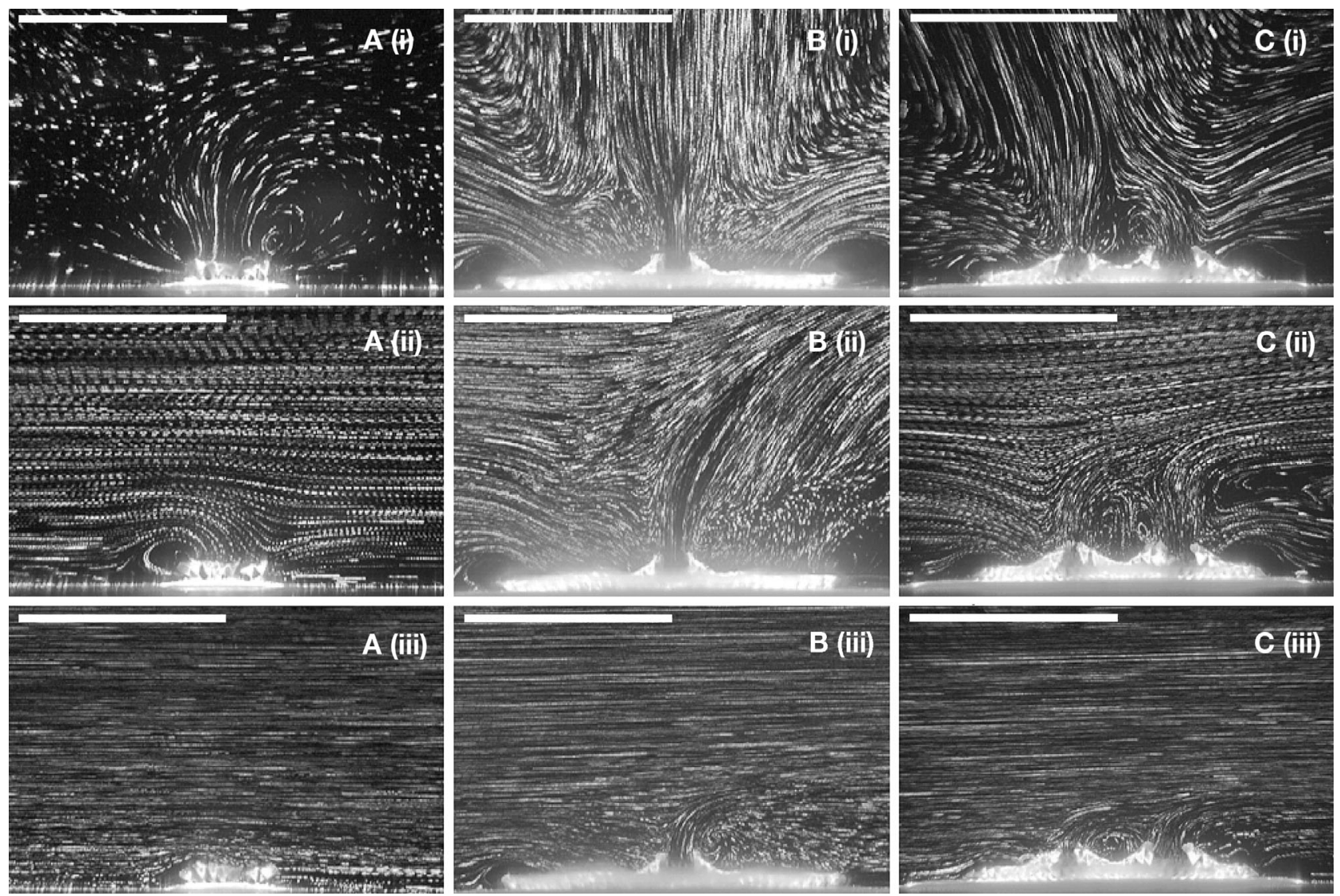

Fig. 7. Membranipora membranacea. Examples of flow around colonies of different sizes at 3 freestream velocities: (A) small colony ( 125 zooids); (B) medium colony ( 975 zooids) with 1 excurrent chimney visible; (C) medium colony ( 975 zooids) with 2 excurrent chimneys visible; (i) $0 \mathrm{~cm} \mathrm{~s}^{-1}$, (ii) $0.5 \mathrm{~cm} \mathrm{~s}^{-1}$; (iii) $2.7 \mathrm{~cm} \mathrm{~s}^{-1}$. Image presentation and scale bars as in Fig. 3

the encrusting form when measured at $3 \mathrm{~cm} \mathrm{~s}^{-1}$ ambient velocity. This result is a little surprising, since previous results indicated that Membranipora, an encrusting sheet in nature, had higher ingestion rates than 2 erect tree species (Bugula pacifica and Scrupocellaria varians) (Pratt 2003). This difference in results may be due to interspecific differences such as shape or size of the lophophores, but variation in the shape of erect forms between studies is also likely to be in important factor.

The enhanced feeding performance of the 2 erect forms was probably primarily due to enhanced mixing and decreased refiltration relative to the encrusting sheet. Refiltration of water can decrease particle flux and decrease particle-capture rates in bryozoans, because water from excurrent flows will typically have a lower concentration of particles (Grünbaum 1995, 1997, Eckman \& Okamura 1998, Larsen et al. 1998, Larsen \& Riisgård 2002, Pratt 2004). If a colony is in still water, it will eventually deplete the water around it of particles. Increasing the water velocity can increase particle flux. Enhanced mixing, such as occurred in the downstream wake of the erect colonies, can enhance particle flux by adding new particles to the water and slowing them down for easier capture. For example, although I never observed zooids in the encrusting sheet colony capturing particles at an ambient velocity of $3 \mathrm{~cm} \mathrm{~s}^{-1}$, I frequently observed zooids on the downstream side of the erect colonies capturing particles at this velocity. Similarly, many suspension feeders separate incurrent and excurrent flows to avoid refiltration (e.g. sponges: Bidder 1923; and colonial ascidians: Vogel 1994) or feed from a relatively well-mixed downstream wake to enhance feeding (the sea anemone Metridium senile: Koehl 1977; and the corals Madracis mirabilis: Sebens et al. 1997, and Agaricia agaricites: Helmuth \& Sebens 1993).

The erect tree form I used was a planar colony in unidirectional flow, which other studies have also found can enhance feeding. Consequently, many suspension-feeding organisms have planar or fan-shaped colonies in unidirectional or bidirectional currents (Riedl 1971). For example, the sea-whip Leptogorgia virgulata assumes a more fan-shaped morphology in the presence of strong bidirectional currents compared 
with colonies in more turbulent habitats; the colonies in bidirectional currents naturally orient perpendicularly to these currents, and feeding rate is higher in colonies that are oriented perpendicular to the dominant flow direction (Leversee 1976).

A planar colony form is rare in bryozoans, which may be due to their tendency to live in more turbulent habitats or because they can actively pump water through their feeding structures and do not need to rely on feeding in a turbulent wake (Ryland \& Warner 1986). Furthermore, in nature, water flow may not always be unidirectional and is often oscillating or turbulent, and oscillating flow affects feeding performance differently than unidirectional flow (Hunter 1989). Therefore, it is important to take the ambient flow environment into consideration when interpreting the size and shape of bryozoan zooids and colonies in the field.

While erect colonies were found to have a feeding advantage in this study, at even higher velocities, erect colonies may be at a disadvantage because high drag can cause deformation of the filtering surface and reduce filtration efficiency (Best 1988), or may increase the risk of dislodgement or damage (Cheetham \& Thomsen 1981, Cheetham 1986).

\section{Colony size}

Previous research on suspension feeders has not revealed a consistent pattern of variation in feeding success as a function of size, with examples of both positive correlations (Metridium senile: Anthony 1997; and Plumatella repens: Okamura \& Doolan 1993) and negative correlations (Lophopodella carteri: Bishop \& Bahr 1973; an unnamed alcyonacean soft coral: McFadden 1986; and Alcyonium siderium: Patterson 1991) with increasing size. For bryozoans, Okamura $(1984,1985)$ found that larger bryozoan colonies generally have higher feeding rates than smaller colonies. In this study, ingestion rates increased as size increased from a single zooid to colonies with 16 zooids, decreased as size increased from 16 zooids to small colonies ( 125 zooids), and increased again as size increased further to medium colonies ( 975 zooids).

However, the consequences of size to feeding can depend on flow. For example, Okamura (1985) found that larger colonies $\left(3.95 \mathrm{~cm}^{2}\right)$ of Conopeum reticulum, an encrusting sheet bryozoan, only had higher feeding success than smaller colonies $\left(0.49 \mathrm{~cm}^{2}\right)$ at relatively slow and medium velocities ( 1 to 2 and 4 to $6 \mathrm{~cm} \mathrm{~s}^{-1}$ ) but not at fast velocities (10 to $12 \mathrm{~cm} \mathrm{~s}^{-1}$ ). The present study reveals similar results when the size of the colony and ambient velocities are taken into consideration, because the 'medium' colonies $\left(3.12 \mathrm{~cm}^{2}\right)$ generally had slightly higher ingestion rates than the 'small' colonies $\left(0.14 \mathrm{~cm}^{2}\right)$ at the relatively low velocities tested $\left(0,0.5\right.$ and $\left.2.7 \mathrm{~cm} \mathrm{~s}^{-1}\right)$.

The lower feeding rate of smaller colonies in slower flows may be a result of the shorter 'reach' of these colonies into the flow above them. A colony will have access to more of the surrounding water if they attain a greater 'reach' due to a faster cilia-generated flow further from the colony. Faster incurrent flows may also decrease the amount of water that is refiltered. I found that single zooids had significantly slower incurrent velocity when $>0.05 \mathrm{~cm}$ above the lophophores, and could not divert particles from as great a distance as colonies with 8 or more zooids. In fact, the larger the colony, the less the incurrent velocity changed with distance from the lophophores. While this difference in incurrent velocity may help explain why 8- and 16-zooid colonies had higher ingestion rates than the single zooids, it does not explain why 8- and 16-zooid colonies had higher ingestion rates than small and medium colonies.

The relatively lower ingestion rates of small and medium colonies compared to colonies of 8 and 16 zooids may have been due to (1) a non-linear relationship between colony size and incurrent flow, (2) more opportunities for refiltration in larger colonies, and (3) increased competition for food between zooids. Incurrent velocity did not increase proportionally with increasing colony size (i.e. the incurrent velocity distant from the lophophores did not double when the number of zooids doubled) possibly because of a greater build-up of pressure on the lophophore canopy of larger canopies. This build-up of pressure would depend upon a balance between incurrent and excurrent areas. The presence of many excurrent chimneys would amelioriate problems with pressure build-up and create a faster excurrent jet, but the presence of chimneys also increases the opportunities available for refiltration (see for example Fig. 3A(iii) and Lidgard 1981). The creation of such chimneys also requires the sacrifice of feeding zooids.

There also appeared to be more competition among neighboring zooids for food particles in larger colonies. For example, at high magnification, I was able to observe particles that were traveling almost vertically at the boundary between 2 lophophores suddenly shift horizontally to one zooid or the other when they got close to the lophophores. Thus, all considered, competing lophophores may have captured fewer particles. This hypothesis can be tested by increasing the particle concentration in the water until saturation so that ingestion rate is not limited by particle flux. In this scenario, competition among zooids for particles should not be a factor and ingestion rate should be dictated more by handling time, which should be the same if the zooids are the same size and can handle the particles at the same rate regardless of colony size. 
While ambient-flow conditions and how the feeding currents interact with the ambient flow are clearly important in determining bryozoan feeding performance (Lidgard 1981, Eckman \& Okamura 1998, Larsen et al. 1998, Okamura \& Partridge 1999, Okamura et al. 2001, Larsen \& Riisgård 2002, Pratt 2004, present study), feeding performance is not the only selective pressure on bryozoan shape and size. Membranipora colonies can grow quite large, sometimes covering kelp blades that are many meters in length; thus, the overall advantages of growing large must outweigh any disadvantages. As long as the colony continues to capture enough food to continue growing, it may be more important to grow large to increase fecundity and survival. Larger colonies may have higher fitness, since fecundity (Hayward 1973, Hayward \& Ryland 1975, Winston \& Jackson 1984, Jackson \& Wertheimer 1985), growth rate (Lutaud 1983, Winston \& Jackson 1984, Hughes \& Hughes 1986) and survivorship (Sutherland \& Karlson 1977, Buss 1981, Russ 1982, Winston \& Jackson 1984) have been shown to increase with increasing colony size for some bryozoans.

While I did not measure growth rates as a function of size in Membranipora, it is possible that larger colonies have faster growth rates. Colonies grow by budding at the perimeter, but perimeter does not increase as fast as area in a circular colony like Membranipora. This means that there will be proportionally more interior zooids per perimeter zooid in larger colonies. This is important, since energy is translocated from those interior zooids to support the growth of the perimeter zooids. For example, $46 \%$ of ingested carbon is lost through respiration and egestion within $24 \mathrm{~h}$ for interior zooids of Membranipora, but $15 \%$ of ingested carbon is translocated to perimeter zooids within $48 \mathrm{~h}$ (Miles et al. 1995). This translocation is particularly important because the perimeter zooids that are budding are not feeding and cannot support themselves. As long as internal zooids acquire enough food to cover their own metabolic cost and can transmit extra energy to perimeter zooids, a higher ratio of internal to perimeter zooids could result in a higher growth rate.

\section{CONCLUSION}

This study comprises a good basis for understanding how colony shape and size affect feeding success as a function of flow; however, more research is needed. The most important next step would be to examine feeding success along with other potential selective factors as a function of colony size and shape under field conditions. Only then can we better understand the present patterns of distribution and abundance, as well as those through evolutionary time.
Acknowledgements. I am grateful for comments made by $\mathrm{S}$. Vogel, D. McShea, C. Cunningham, W. Kier and E. Shaughnessy on early drafts of this manuscript, and for comments by A. S. Johnson and O. Ellers on later drafts. I thank A. O. D. Willows and staff for providing facilities and support at the Friday Harbor Laboratories. I was supported by an American Dissertation Fellowship from the American Association of University Women, a Wainwright Fellowship from the Friday Harbor Laboratories, and a Doctoral Dissertation Improvement Grant (IBN-0206457) from the National Science Foundation during the course of this research. I am also thankful for the support from the post doctoral fellowship as the Scholar-in-Residence at Bowdoin College's Coastal Studies Center during the preparation of this manuscript.

\section{LITERATURE CITED}

Anthony KRN (1997) Prey capture by the sea anemone Metridium senile (L): effects of body size, flow regime, and upstream neighbors. Biol Bull (Woods Hole) 192:73-86

Best BA (1988) Passive suspension feeding in a sea peneffects of ambient flow on volume flow-rate and filtering efficiency. Biol Bull (Woods Hole) 175:332-342

Bidder GP (1923) The relationship of the form of a sponge to its currents. Q J Microsc Sci 67:292-323

Bishop JW, Bahr LM (1973) Effects of colony size on feeding by Lophopodella carteri (Hyatt). In: Boardman RS, Cheetham AH, Oliver WA (eds) Animal colonies: development and function through time. Dowden, Hutchinson \& Ross, Stroudsburg, PA, p 433-437

Buss LW (1979a) Bryozoan overgrowth interactions-the interdependence of competition for space and food. Nature 281:475-477

Buss LW (1979b) Habitat selection, directional growth and spatial refuges: why colonial animals have more hiding places. In: Larwood G, Rosen BR (eds) Biology and systematics of colonial organisms. Academic Press, New York, p 459-497

Buss LW (1981) Mechanisms of competition between Onychocella alula (Hastings) and Antropora tincta (Hastings) on an Eastern Pacific rocky shoreline. In: Larwood GP, Nielsen C (eds) Recent and fossil Bryozoa. Olsen \& Olsen, Fredensborg, p 39-49

Cancino JM, Hughes RN (1988) The zooidal polymorphism and astogeny of Celleporella hyalina (Bryozoa: Cheilostomata). J Zool 215:167-182

Cheetham AH (1986) Branching, biomechanics and bryozoan evolution. Proc R Soc Lond Ser B Biol Sci 228:151-172

Cheetham AH, Thomsen E (1981) Functional morphology of arborescent animals: strength and design of cheilostome bryozoan skeletons. Paleobiology 7:355-383

Coates AG, Jackson JBC (1985) Morphological themes in the evolution of clonal and aclonal marine invertebrates. In: Jackson JBC, Buss LW, Cook RE (eds) Population biology and evolution of clonal organisms. Yale University Press, New Haven, p 67-106

Dick MH (1987) A proposed mechanism for chimney formation in encrusting bryozoan colonies. In: Ross JRP (ed) Bryozoans: present and past. Western Washington University Press, Bellingham, p 73-80

Eckman JE, Okamura B (1998) A model of particle capture by bryozoans in turbulent flow: significance of colony form. Am Nat 152:861-880

Grünbaum D (1995) A model of feeding currents in encrusting bryozoans shows interference between zooids within a colony. J Theor Biol 174:409-425 
Grünbaum D (1997) Hydrodynamical mechanisms of colony organization and cost of defense in an encrusting bryozoan, Membranipora membranacea. Limnol Oceanogr 42:741-752

Harper JL (1985) Modules, branches, and the capture of resources. In: Jackson JBC, Buss LW, Cook RE (eds) Population biology and evolution of clonal organisms. Yale University Press, New Haven, p 1-33

Hayward PJ (1973) Preliminary observations on settlements and growth in populations of Alcyonidium hirsutum (Fleming). In: Larwood GP (ed) Living and fossil Bryozoa. Academic Press, London, p 107-113

Hayward PJ, Ryland JS (1975) Growth, reproduction, and larval dispersal in Alcyonidium hirsutum (Fleming) and some other Bryozoa. Pubbl Stn Zool Napoli 39:226-241

Helmuth B, Sebens K (1993) The influence of colony morphology and orientation to flow on particle capture by the scleractinian coral Agaricia agaricites (Linnaeus). J Exp Mar Biol Ecol 165:251-278

Hughes DJ, Hughes RN (1986) Metabolic implications of modularity: studies on the respiration and growth of Electra pilosa. Phil Trans R Soc Lond B 313:23-29

Hunter T (1989) Suspension feeding in oscillating flow: the effect of colony morphology and flow regime on plankton capture by the hydroid Obelia longissima. Biol Bull (Woods Hole) 176:41-49

Jackson JBC (1979) Morphological strategies of sessile animals. In: Larwood G, Rosen BR (eds) Biology and systematics of colonial organisms, Vol 11. Academic Press, New York, p 499-555

Jackson JBC, Wertheimer S (1985) Patterns of reproduction in five common species of Jamaican reef-associated bryozoans. In: Nielsen C, Larwood GP (eds) Bryozoa: Ordovician to Recent. Olsen \& Olsen, Fredensborg, p 161-168

Koehl MAR (1977) Effects of sea anemones on the flow forces they encounter. J Exp Biol 69:87-105

Koehl MAR, Alberte RS (1988) Flow, flapping, and photosynthesis of Nereocystis luetkeana: a functional comparison of undulate and flat blade morphologies. Mar Biol 99: 435-444

Larsen PS, Riisgård HU (2002) On ciliary sieving and pumping in bryozoans. J Sea Res 48:181-195

Larsen PS, Matlok SS, Riisgård HU (1998) Bryozoan filter feeding in laminar wall layers: flume experiments and computer simulation. Vie Milieu 48:309-319

Lasker HR, Sanchez JA (2002) Astogeny and allometery of modular colonial organisms. In: Hughes RN (ed) Progress in asexual reproduction, Vol 11. John Wiley \& Sons, Chichester, p 207-253

Leversee GJ (1976) Flow and feeding in fan-shaped colonies of the gorgonian coral, Leprogorgia. Biol Bull (Woods Hole) 151:344-356

Lidgard S (1981) Water flow, feeding, and colony form in an encrusting cheilostome. In: Larwood GP, Nielsen C (eds) Recent and fossil Bryozoa. Olsen \& Olsen, Fredensborg, p 135-143

Lidgard S (1985a) Budding process and geometry in encrusting cheilostome bryozoans. In: Nielsen C, Larwood GP (eds) Bryozoa: Ordovician to Recent. Olsen \& Olsen, Fredensborg, p 175-182

Lidgard S (1985b) Zooid and colony growth in encrusting cheilostome bryozoans. Paleontology 28:255-291

Lisbjerg D, Petersen JK (2001) Feeding activity, retention efficiency, and effects of temperature and particle concentration on clearance rate in the marine bryozoan Electra crustulenta. Mar Ecol Prog Ser 215:133-141

Lutaud G (1983) Autozooid morphogenesis in anascan cheilo- stomes. In: Robison RA (ed) Treatise on invertebrate paleontology, Part G, Bryozoa, revised. University of Kansas \& Geological Society of America, Lawrence, KS, p 208-237

McFadden CS (1986) Colony fission increases particle capture rates of a soft coral: advantages of being a small colony. J Exp Mar Biol Ecol 1986:1-20

McGhee GR Jr, McKinney FK (2000) A theoretical morphologic analysis of convergently evolved erect helical colony form in the Bryozoa. Paleobiology 26:556-577

McKinney FK (1989) Two patterns of colonial water flow in an erect bilaminate bryozoan, the cheilostome Schizotheca serratimargo (Hincks, 1886). Cah Biol Mar 30:35-48

McKinney FK (1990) Feeding and associated colony morphology in marine bryozoans. Rev Aquat Sci 2:255-280

McKinney FK, Jackson JBC (1991) Bryozoan evolution. University of Chicago Press, Chicago

McKinney FK, Raup DM (1982) A turn in the right direction: simulation of erect spiral growth in the bryozoans Archimedes and Bugula. Paleobiology 8:101-112

McKinney FK, Listokin MRA, Phifer CD (1986) Flow and polypide distribution in the cheilostome bryozoan Bugula and their inference in Archimedes. Lethaia 19:81-93

Miles JS, Harvell CD, Griggs CM, Eisner S (1995) Resource translocation in a marine bryozoan: quantification and visualization of ${ }^{14} \mathrm{C}$ and ${ }^{35} \mathrm{~S}$. Mar Biol 122:439-445

Okamura B (1984) The effects of ambient flow velocity, colony size and upstream colonies on the feeding success of Bryozoa: 1. Bugula stolonifera, an arborescent species. J Exp Mar Biol Ecol 83:179-194

Okamura B (1985) The effects of ambient flow velocity, colony size and upstream colonies on the feeding success of Bryozoa: 2. Conopeum reticulum, an encrusting species. J Exp Mar Biol Ecol 89:69-80

Okamura B (1990) Particle size, flow velocity, and suspensionfeeding by the erect bryozoans Bugula neritina and Bugula stolonifera. Mar Biol 105:33-38

Okamura B, Doolan LA (1993) Patterns of suspension feeding in the freshwater bryozoan Plumatella repens. Biol Bull (Woods Hole) 184:52-56

Okamura B, Partridge JC (1999) Suspension feeding adaptations to extreme flow environments in a marine bryozoan. Biol Bull (Woods Hole) 196:205-215

Okamura B, Harmelin JG, Jackson JBC (2001) Refuges revisited: enemies versus flow and feeding as determinants of sessile animal distribution and form. In: Jackson JBC, Lidgard S, McKinney FK (eds) Evolutionary patterns: growth, form, and tempo in the fossil record. University of Chicago Press, Chicago, p 61-93

Patterson MR (1991) Passive suspension feeding by an octocoral in plankton patches: empirical test of a mathematical model. Biol Bull (Woods Hole) 180:81-92

Pratt MC (2003) Flow, feeding and form: consequences of coloniality in bryozoans. PhD dissertation, Duke University, Durham, NC

Pratt MC (2004) The effect of zooid spacing on bryozoan feeding success: is competition or facilitation more important? Biol Bull (Woods Hole) 207:17-27

Riedl R (1971) Water movement: animals. In: Kinne O (ed) Marine ecology: a comprehensive, integrated treatise on life in oceans and coastal waters, Vol 1. Wiley-Interscience, London, p 1123-1156

Russ GR (1982) Overgrowth in a marine epifaunal community: competitive hierarchies and competitive networks. Oecologia 53:12-19

Ryland JS, Warner GF (1986) Growth and form in modular animals: ideas on the size and arrangement of zooids. Phil Trans R Soc Lond B 313:53-76 
Sebens KP, Witting J, Helmuth B (1997) Effects of water flow and branch spacing on particle capture by the reef coral Madracis mirabilis (Duchassaing and Michelotti). J Exp Mar Biol Ecol 211:1-28

Silén L (1982) Multizooidal budding in Parasmittina trispinosa (Bryozoa, Cheilostomata). Acta Zool (Stockh) 63:25-32

Silén L (1987) Colony growth pattern in Electra pilosa (Linnaeus) and comparable encrusting cheilostome bryozoans. Acta Zool (Stockh) 68:17-34

Starcher RW, McGhee GR Jr (2000) Fenestrate theoretical morphology: geometric constraints on lophophore shape and arrangement in extinct Bryozoa. Paleobiology 26:116-136

Sutherland JP, Karlson RH (1977) Development and stability of the fouling community at Beaufort, North Carolina. Ecol Monogr 47:425-446

Taylor PD, Wilson MA (1994) Corynotrypa from the Ordo-

Editorial responsibility: Otto Kinne (Editor-in-Chief), Oldendorf/Luhe, Germany vician of North America: colony growth in a primitive stenolaemate bryozoan. J Paleontol 68:241-257

Vogel S (1994) Life in moving fluids: the physical biology of flow. Princeton University Press, Princeton, NJ

Vogel S, LaBarbera M (1978) Simple flow tanks for research and teaching. BioScience 28:638-643

Winston JE (1978) Polypide morphology and feeding behavior in marine ectoprocts. Bull Mar Sci 28:1-31

Winston JE (1979) Current-related morphology and behaviour in some Pacific coast bryozoans. In: Larwood GP, Abbott MB (eds) Advances in bryozoology, Vol 13. Academic Press, New York, p 247-268

Winston JE, Jackson JBC (1984) Ecology of cryptic coral reef communities: 4. Community development and life histories of encrusting cheilostome bryozoa. J Exp Mar Biol Ecol 76:1-22

Submitted: July 22, 2004; Accepted: June 11, 2005

Proofs received from author(s): October 21, 2005 